\title{
Impact Analysis of Ban of Commercial Motorcycle on Commuters in the University of Ibadan Campus
}

\author{
Ayomide Famewo $^{1 *} \quad$ Kayode Adeniji $^{2} \quad$ Paul Onibaba $^{3} \quad$ Olawale Osunwale $^{1}$ \\ 1.Department of Urban and Regional Planning, Faculty of Environmental Design and Management, University \\ of Ibadan, Ibadan, Nigeria \\ 2.Department of Urban and Regional Planning, Osun State University, Osogbo, Nigeria \\ 3.Department of Urban and Regional Planning, Federal University of Technology, Akure, Nigeria
}

\begin{abstract}
In Nigeria, commercial motorcycle operations (CMO) can be traced back to the period 1970-1980. Their emergence is primarily a result of public transport failure and economic downturn in that period. Up until recently, CMO have been a major means of intra-city public transport. Now, its operations have been prohibited or limited in many urban centers and campuses due to its connection to crime and high risk of accidents. Many studies have attempted to research the impacts of its ban on urban commuters' traffic behavior, with total neglect for campuses. Hence, this study attempts to assess the impacts of ban of CMO on commuters in the University of Ibadan Campus, within a year, its activities was proscribed. The study adopted survey research design. Primary and secondary data were sourced. Both random and purposive sampling techniques was used in selecting 300 students from a total students population of 35000 and 50 staff from a total staff population 3,684. A set of pre-tested questionnaire was administered on 350 commuters comprising mainly of students and staff selected randomly from the total student and staff population. Information gathered includes socio-economic characteristics of university commuters (students and staff), social economic impacts of ban of commercial motorcycles and its impacts on students' activities on campus. Data obtained were analyzed using both descriptive (tables, frequency counts and percentage.) and inferential (T-test and Chi Square) statistics. Two hypotheses were formulated and tested. Paired sample t-test statistics was used to analyze the difference between cost of trips before ban of commercial motorcycles operations in the university and after the ban. The results of the analysis revealed that cost of trips increased significantly by $\$ 15.28$ ( $p=0.045$ ). Chi square test was used to test significance difference in university commuters' modal mode of transport before and after the ban. The chi square results gives a chi square value 74.235 which is significant $(p=.000)$. Thus, the study confirmed that the ban of commercial motorcycles operations in the university have significant negative impacts on university commuters, especially students. The study therefore, suggest an inclusive transportation policy for university community, one that focus development on infrastructure, improvement in transport infrastructure and effective management of university commuters' demand.
\end{abstract}

Keywords: Impact Analysis; Ban of Commercial Motorcycle operations; University of Ibadan; campus planning; commuter.

DOI: $10.7176 / \mathrm{DCS} / 10-6-07$

Publication date:June $30^{\text {th }} 2020$

\subsection{Introduction}

Transportation has been found to play significant role in the development of cities and by extension university campus. The need for sustainable mobility justify the rationale for transportation planning. Based on priori expectation, there ought to be a positive relationship between development of a place and its transport system. Thus, campus transport system would depend on level of development within the campus, modal choice available and the specific mode of transport. More pointedly, university campus transport system often reflects a model of intra-city transportation system. University transport system should be seen primarily as the movement of staff, students, visitors and others to, from and within the university campus and its nearby surroundings.

Although, university transport planning forms an integral part of campus development. This is essential because the university campus often have centralized land use system, yearly change in student population, peculiar topography, thus, its traffic demand would be determined by its activities. Yet, transportation planning in university campuses have been neglected overtime (Busari, et al, 2015). As observed by Tolley (1996), in the past few decades, there are limited means of transport in many university campuses. Thus, Shannon et al (2006) believes that a sustainable transport planning for campuses will require present realities in traffic demand in these campuses, which will require a survey of its commuters, principally students and staff. It can be implied that the prevailing transport system in a campus will depends on its land uses, access to facilities and spaces within the campus.

In Nigeria and elsewhere, the mode of transport common to university system includes bus shuttles, cabs, motorcycles, personal vehicles, bicycles, walking and etc. These modes are either publicly or privately managed. Thus, road transport happens to be the dominant means of transport in many campuses. Hence most transport development in campus often followed the pattern of intra-city transport development prevalent in the country. 
However, these can be largely influenced by local topography, vehicle ownership and availability of sidewalks. More precisely, topography and vehicle ownership influence motorized transport within the campus while presence of sidewalks affects utilization of non- motorized transport for campus commuters. (Limanond et al. 2011; Rodriguez and Joo, 2004). Although, the use of bicycle has been suggested to be the best modal choice for short distances within the university campus and off campus students (Tolley, 1996). Its ability to actively engage the commuter and also lowering $\mathrm{Co}_{2}$ emissions and promoting health (Mumomachi, 2008; Shannon et al., 2006). However, its excessive use have been linked with increase rate of accidents between commuters and vehicles or pedestrians on narrow roads without a separate lane for bicycle.

The two main determinants of the campus to generate traffic depends on the students and staff strength when school is in session. The functional size of a campus to become a traffic generator will depend on staff employment and students' intake, as these commuters often uses the campus comparatively to other visitors who perform services or available at weekends for special events.

The proliferation of the use of commercial motorcycle operations in Nigerian university is largely connected to its evolution in the country. The evolution of commercial motorcycle operations in Nigerian cities is traceable to the late 1980s (Gadonu et al. 1979 \& Adeniji, 1980). Reasons that accounted for its wide use include the deterioration of the intra-city transport system due to population growth around that time. For instance, the population of Lagos, Ibadan, Kaduna, Port-Harcourt and other major cities doubled within the period (1970-1980) while the transport infrastructure within these cities deteriorated within the same period.

Similarly, as averred by Oyesiku (2002) there was decrease in the supply of new vehicles, which contribute to the proliferation of commercial motorcycle. Lastly, Ogunsanya and Galtima (1993) averred that economic depression and poor transport infrastructure are the dominant factors responsible for commercial motorcycle operations. The views of these authors suggest that motorcycle proliferation in Nigeria is a problem of population growth with negative impacts on transport infrastructure and economic status of residents. Thus, from the 1970, there was a continuous growth in commercial motorcycle as a means of public intra-city transportation.

Similarly, in many urban centers in Asia, motorcycles have become a major mode of urban transport, primarily because of their flexibility and their attraction of the low and middle income earners because of relative price (Barter, 1998; Tuan et al., 2005; Koizumi et al., 2013).

According to Michael et al, (2013) motorcycle as a means on intra-city transportation is largely patronized for the following; reasons eagerness to reach destination with minimal delay, its relative cheaper cost, availability, accessibility and ability to maneuver bad roads. These reasons can be extended to its adoption within the university system especially in large urban centers in Third World Cities. Students and staff finds the motorcycle as way of meeting up with early morning lecture or official work resumption time and does not to wait for another passenger before it takes off.

Thus, based on the advantages of the motorcycle generally and the peculiarity of the transport system in universities such as the limited short distances for connecting facilities and student residences, thus led to the adoption of its use in many campuses. The evolution of the commercial motorcycle operations in the university campus may not be unconnected to the failure of an effective master plan for the campus at the initial and the continuous failure of changes in physical development to influence changes to transportation or lack of integration of transport plan with the physical development plan of the university. In the University of Ibadan campus, the motorcyclists' operators were registered with the intra-campus transport committee to operate within the campus and they often renew their permit on yearly basis until June $30^{\text {th }} 2019$, when their activities were proscribed.

It is not only in the University of Ibadan campus that motorcycle operations have been banned, but also in many cities in sub-Saharan Africa and Asia cities such as Lagos, Nigeria, Guangzhou, China and Myammar, Indonesia (Deng et al, 2009 Inaba \& Kato, 2017). Notable factors accounting for its ban includes, its increase in road accidents, leading to deaths and permanent disabilities, for instance, it accounted for $21 \%$ of all accidents in Lagos city, in 1999, air pollution within the city, greenhouse gas emissions, noise pollution, recklessness, refusal to comply traffic rules and other traffic management problems (Ndiribe, 2009, Kumar, 2011 and Olubomehin, 2012).

In a study by Inuwa et al, (2017) in Gombe metropolis, it was observed that Commercial Motorcycle operations have significant positive impact on urban livelihoods and engage the teeming youth, thus, keeping them away from criminal activities. Similarly, Ikot et al (2011) assessed the impacts of commercial motorcycles in Uyo Metropolis and found that there is connection between its ban and the level of insecurity and crime prevalent in the state. Hence, the need to create employment opportunities and skills acquisition in mitigating the gap.

Despite the reasons accounting for its ban and inconclusive nature on its socio-economic benefits, yet, there have been negative impacts of its on residents and their traffic behavior. For instance, Deng et al (2009) carried out a study on the impacts of ban of motorcycles in urban areas in Guangzhou, China from 2007-2009 and the study found that the ban had reduce the use of motorcycles and increased the use of other public transportation means such as cars. Similarly, Ye et al (2011) assessed the impacts of motorcycle ban policy on residents in Huizhou, China using travel preference data of residents. The study found out that as motorcycle ban policy 
suppresses the use of motorcycle but promotes the use of other modes of transportation. These studies reveal the impacts of ban on individual's modal choices.

Inaba \& Kato (2017) extended the impacts of motorcycle ban on traffic generation and vehicle ownership by integrating traffic assignment and vehicle ownership model in forecasting the potential impacts of ban of motorcycles in Myammar since 2003 in 2013 and 2035. They found that ban would reduce traffic volume and distance travelled in the two periods significantly. Specifically, the ban is expected to mitigate present urban transportation challenges, however would promote car ownership, a situation many urban centers will like to discourage in favor of public transportation. Thus, it is important to understand the long-term effects of ban of motorcycle operations especially as a means of intra-city transportation. However, this study assess the impacts of ban of commercial motorcycle operations in the university system within a year its activities were banned, with a view to suggest policy measures that can mitigate both its short and long term effects on university commuters.

\subsection{Material and Methods}

The study was conducted in the University of Ibadan Campus. The Campus is located in Ibadan, the Oyo State capital and falls under Ibadan North Local Government Area. Its coordinate's extent lies between Longitude $3.9000^{\circ} \mathrm{E}$ and Latitude $7.4417^{\circ} \mathrm{N}$. The University was founded in 1948 as the University College, Ibadan (UCI) and begin its activities at Eleyele before moving to its present site, which is over 2,250 acres. The University started with three faculties; Arts, Medicine and Science with 104 foundation students but has about sixteen faculties with relatively new faculties such as Environmental Design Management, Public Health etc.

It became a full-fledged university in 1961. The University is fondly referred to as UI and it is one of the first generation university in the country with a global vision for academic excellence. Most importantly, the institution strive to achieve excellence in the area of research, meeting societal need and impacting knowledge. The university is fully residential, with twelve halls of student residence, including ten undergraduates and two postgraduates with capacity for 8000 students. As at present, the total student population is 35,000 which comprises of both undergraduate and postgraduate students. And a staff strength of 3,684, with 2,604 academic staff, 935 senior staff and 1080 junior staff. 


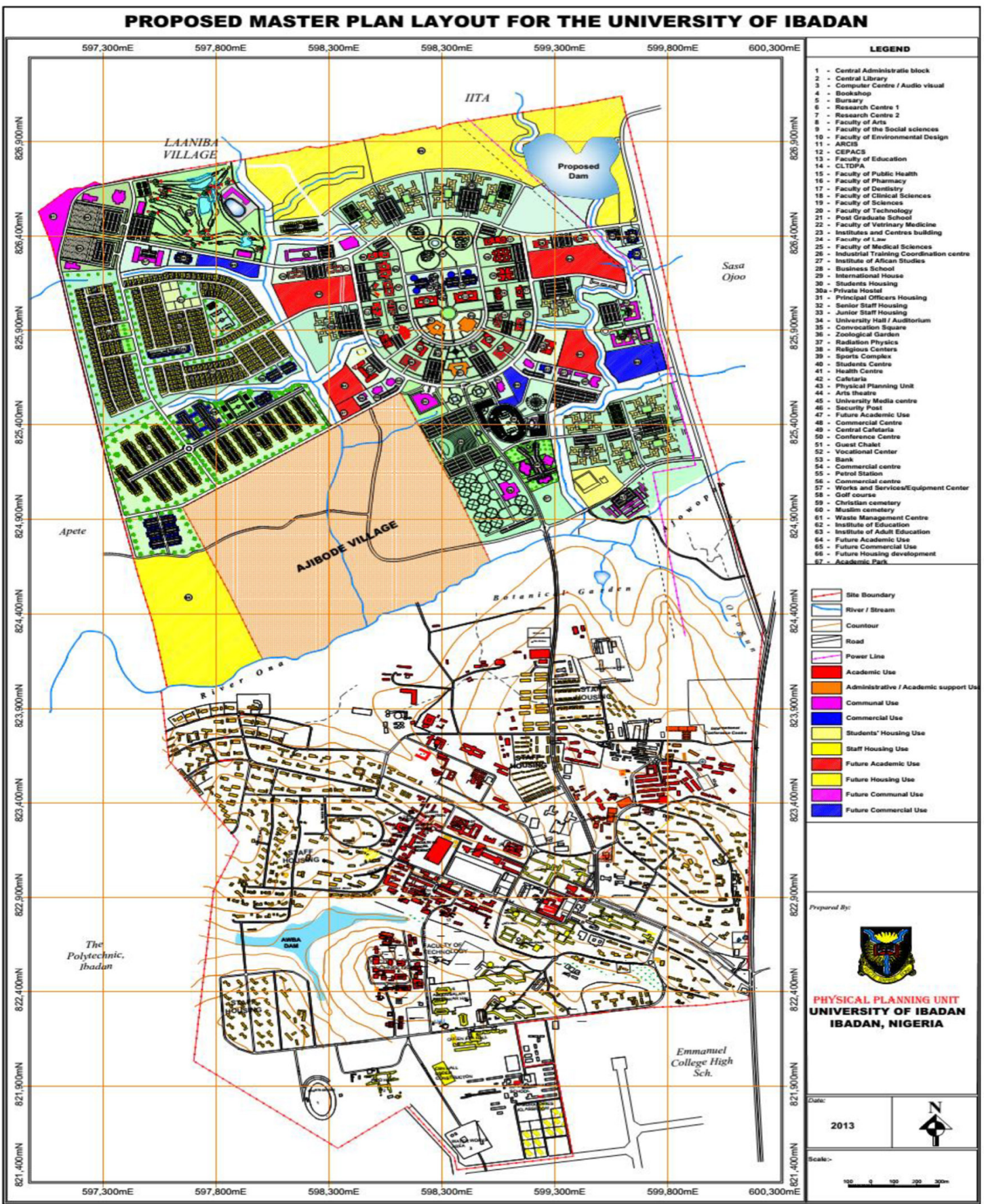

Fig 1: University of Ibadan master's plan Source: Physical Planning Unit, University of Ibadan, Nigeria

\subsection{Methods}

The study adopted a survey research design. Both random and purposive sampling technique was used to select 300 students from the total student population of 35,000, which comprises of both undergraduate and postgraduate students of the University of Ibadan. Also, 50 staff was selected from the total staff strength of 4,619, which comprises of academic staff $(2,604)$, senior staff $(935)$ and junior staff $(1,080)$. A ratio of one staff to 9 student was adopted for the survey based on the differences in the ratio of student to staff. A total sample size of 350 was gotten.

Both primary and secondary data were sourced for the study. Primary data were sourced through the use of a set pre-tested structured questionnaire designed for students and staff. The questionnaire was structured into three segments to elicit information on social economic characteristics of university commuters (type of commuter, location, age, average income/stipends, and sex and vehicle ownership), social economic impacts of ban of commercial motorcycle on commuters, impacts of ban students' activities on campus. Secondary data were 
sourced from relevant journals, internet searches, maps, from the university physical planning unit and other relevant information from the university website). Data obtained were analyzed using descriptive and inferential (t- test and Chi Square) statistics.

\subsection{Results and Discussion}

Results of investigations conducted in the study are presented under three broad sub-headings: socio-economic characteristics of respondents, impacts of ban of CMO on activities in campus and social economic impacts of ban of CMO on commuters. Two hypotheses were formulated for the study and were tested.

\subsection{Social Economic Characteristics of sampled University commuters}

The analysis in Table 3.1 revealed that $85.7 \%$ of the sampled commuters were students, which comprises of more than half (53\%) undergraduate students and $47 \%$ of sampled students were postgraduate students and $14.3 \%$ were staff which comprises of both the teaching and non-teaching staff. Also, it was observed that more than two-thirds (64\%) of sampled students lived within the campus, while $36 \%$ lived outside the campus. For staff, it was revealed that only $28 \%$ lived within the campus and a majority $(72 \%)$ lived outside the campus. The result implies that majority of university commuters were students, majority of which stayed within campus, while majority of staff stay outside the campus. Broadly, more than half $(58.9 \%)$ of commuters stay within the campus and two-fifths $(41.4 \%)$ commuters stayed outside the campus. Analysis of vehicle ownership revealed that more than nine-tenths $(99.3 \%)$ of sampled students do not won a car and more than one fifths $(24 \%)$ of staff owns a vehicle. Staff vehicle ownership will depend on whether they are academic and senior staff or junior staff. It is expected that more of the academic and senior staff will own a car as against junior staff. As opined by Limmanond et al. (2011) vehicle ownership will be largely influenced traffic behavior and especially for motorized transport in a university transport system. Thus, it can be implied that a lot of commuters within the university campus especially students will rely on centralized campus transport modes.

Table 3.1: Social Economic Characteristics of sampled University commuters

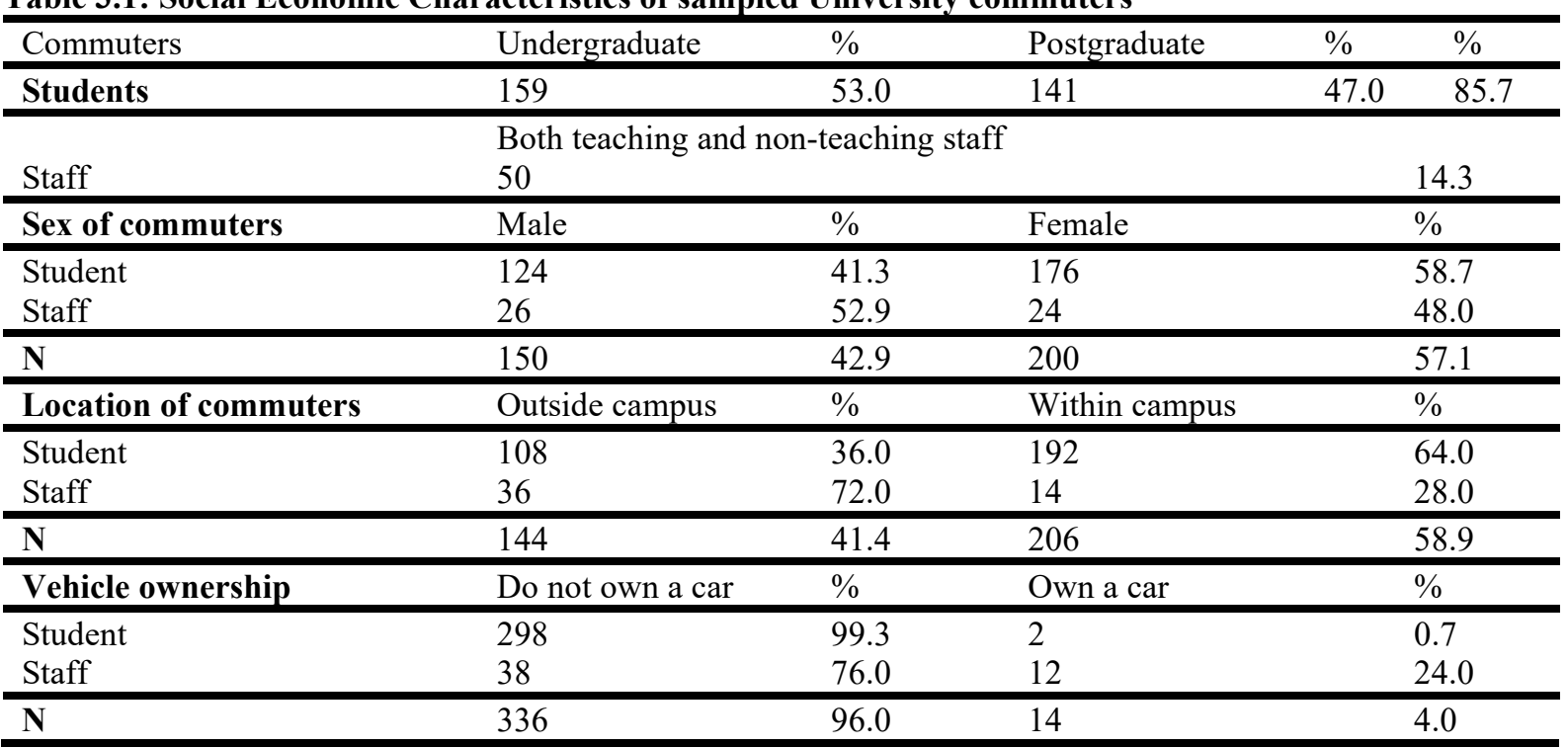

Source: Authors' Analysis, 2020.

\subsection{Comparative Analysis of Students stipends and Staff disposable Income}

The analysis in Table 3.2 reveals that the minimum stipend student receives is $\# 5000$ and maximum stipend received was \#85, $000(\$)$. More than two fifths $(44.1 \%)$ of students receives a monthly stipend that ranges between \#10,001-\#20,000 and about 15.7\% earn above \#40,0001. For staff disposable income, about one fifth (20\%) earn between $\# 36,000$ and $\# 50,000$, about two fifths (44\%) earn between \#50,001 and100, 000 and about $6 \%$ earn above $\# 150,001$. The minimum disposable income was \#36,000 and the maximum disposable income was \#250,000. Staff disposable income was sought because it was this that was available for their spending after all other deductions have been made. The results implies a contrast between the stipends earned by students and disposable income, thus, since students are the dominant commuter in a university system, it is expected that they will be more affected by the ban of commercial motorcycle since its fare rate is cheap and can also help students be in class on time. It would be easier for staff to shift to other mode of transport after the ban than students. 
Table 3.2: Comparative Students Stipends and Staff disposable Income

\begin{tabular}{lll|lll}
\hline Monthly Stipends & Respondents & Percent & $\begin{array}{l}\text { Disposable monthly Income } \\
\text { of staff }\end{array}$ & Respondents & Percent \\
\hline $5000-10,000$ & 81 & 27.1 & $36,000-50,000$ & 10 & 20.0 \\
$10001-20,000$ & 132 & 44.1 & $50,0001-100,000$ & 22 & 44.0 \\
$20,001-30,000$ & 39 & 13.0 & $100,001-150,000$ & 15 & 30.0 \\
$30,001-40,000$ & Nil & Nil & Above 150,001 & 3 & 50 \\
Above 40,0001 & 47 & 15.7 & N & & 100.0 \\
Missing & 1 & 0.1 & & 250,000 & \\
\hline N & 300 & 100.0 & & & \\
\hline Maximum & 85,000 & & & & \\
\hline
\end{tabular}

Source: Authors' Analysis, 2020 NB: ER as at January, $20201 \$=\$ 360$ (CBN database)

\subsection{Age of Commuters}

Presented in Table 3.4 is age cohorts for sampled students and staff in the University campus. Students age cohort revealed that about two-fifths (40.7) of student surveyed were within the cohort of 22-26, about one third (32.7\%) were within age cohort 17-21 and about $6.3 \%$ sampled students were between age cohort 32-36. The result implies a youthful population. Age of commuter could influence his traffic behavior and modal choice, students who are very young and agile will prefer the motorcycle ride as against other means of transport within the campus. For staff, about $28 \%$ were between ages $32-36,24 \%$ were between age cohorts $47-51,22 \%$ were within age cohort 37 41 and about $2 \%$ were above 62 . The staff had an older population than the student as expected, predominantly in their late thirties and forties. As expected the older people become, the change in their traffic behavior. As older population become more risk averse, thus the staff may be happy or indifferent about the ban of CMO within the campus. Since age is a factor influencing traffic behavior, policy makers ought to consider students as priority in transport policy within campuses.

Table 3. 4: Age cohorts of students and staff commuters in the Campus

\begin{tabular}{|c|c|c|c|c|c|}
\hline $\begin{array}{l}\text { Students Age } \\
\text { cohort }\end{array}$ & Respondent & Percent & $\begin{array}{l}\text { Staff age } \\
\text { cohort }\end{array}$ & Respondents & Percent \\
\hline $17-21$ & 98 & 32.7 & $32-36$ & 14 & 28.0 \\
\hline $22-26$ & 122 & 40.7 & $37-41$ & 11 & 22.0 \\
\hline $27-31$ & 42 & 14.0 & $42-46$ & 10 & 20.0 \\
\hline $32-36$ & 19 & 6.3 & $47-51$ & 12 & 24.0 \\
\hline No respondent & 19 & 6.3 & $52-56$ & 2 & 4.0 \\
\hline \multirow[t]{3}{*}{$\bar{N}$} & 300 & 100.0 & $57-61$ & - & - \\
\hline & & & Above 62 & 1 & 2.0 \\
\hline & & & $\mathrm{N}$ & 50 & 100.0 \\
\hline
\end{tabular}

Source: Authors' Analysis, 2020.

\subsection{Dominant Impacts of ban of CMO on Different categories of commuters in the campus \\ 3.4.1 Impacts of Ban of CMO on students traffic behavior}

It is observed in Table 3.5 that more female students have increased transport cost as compared to male as a result of ban of CMO. However, more males are delayed than female and more female experienced congestion than male as a result of ban. There are two peak periods in the university of Ibadan campus, the early morning peak period (07-10am) and late evening (4-6pm). Classes and other school activities happens within the early hours of the day, thus increasing traffic demand with a bias on female students who may not be able to struggle for these mode like their male counterparts. Most often than not for female students uses a price bargain to influence drivers/riders decision, by asking to take a drop. This increases transport cost for all student commuters, increases the chances of female to compete favorably with their male counterparts who might use aggression and also help riders/drivers enjoy economic surplus.

Table 3.5: Main Impacts of Ban based on student's gender

\begin{tabular}{lllll}
\hline Impacts & Female & Percent & Male & Percent \\
\hline Cost & 98 & 55.7 & 56 & 45.2 \\
Delay & 56 & 31.8 & 60 & 48.4 \\
Congestion & 22 & 12.5 & 8 & 6.4 \\
\hline $\mathrm{N}$ & 176 & 100.0 & 124 & 100 \\
\hline
\end{tabular}

Source: Authors' Analysis, 2020. 


\subsubsection{Main Impacts of ban on students outside campus}

The analysis in Table 3.6 reveals that more than half of students outside campus who have to come into school areas on daily basis experienced congestion, about $36.1 \%$ experienced delays and only $6.5 \%$ affirmed that their transport cost increases as a result of ban of CMO activities. Increased waiting time will indirectly influence cost in the long run and also have other opportunity cost such as lateness to class, failure to submit assignment on time, etc.

Table 3.6: Main impacts on Students outside campus

\begin{tabular}{lll}
\hline Impacts & Respondents & Percent \\
\hline Cost & 7 & 6.5 \\
Delay & 39 & 36.1 \\
Congestion & 62 & 57.4 \\
\hline $\mathrm{N}$ & 108 & 100 \\
\hline
\end{tabular}

Source: Authors' Analysis, 2020.

\subsubsection{Main Impact of CMO on staff traffic behavior based on location}

Detailed in Table 3.7 are the results of the dominant impacts of the ban of CMO on staff traffic behavior based on their location. A majority (97.2\%) of staff located outside campus experienced delays as the dominant impact. For staff within the campus, more than half (57.1\%) experienced congestion and more than one third $(35.7 \%)$ experienced delays. The result, therefore, suggest that delay was the dominant factor affecting staff traffic behavior outside, in contrast to those outside the campus, where more than a half (57.1\%) affirm congestion and more than one third (35.7\%) experienced delays. However, there is positive association between delays and congestion, thus, we can assume that both congestion and delays jointly influence staff traffic behavior and are influenced as a result of the ban of CMO.

Table 3.7: Impacts of ban of CMO on staff based on location

\begin{tabular}{lllll}
\hline Main impacts & Staff located outside the campus & Percent & Staff within the campus & Percent \\
\hline Cost & 35 & 97.2 & 1 & 7.2 \\
Delay & - & - & 5 & 35.7 \\
Congestion & 1 & 2.8 & 8 & 57.1 \\
\hline N & 36 & 100.0 & 14 & 100.0 \\
\hline
\end{tabular}

Source: Authors' Analysis, 2020.

\subsubsection{Impacts of Ban of CMO on activities on campus}

Detailed in Table 3.8 is the weighted opinions and ranking of commuters responses on the impacts of the ban of $\mathrm{CMO}$ on activities within the campus. The study examined nine variables based on commuter's assessment. It was gathered that the first five ranked activities includes increases waiting time at bus stop ( $\left.1^{\text {st }}\right)$, increase tensions during early morning exams and long queue at bus stops $\left(2^{\text {nd }}\right)$, difficulty for those living in far residences to connect vehicles plying their routes $\left(3^{\text {rd }}\right)$, increase in struggle for bus/ shuttles, cabs and tricycles at peak period $\left(4^{\text {th }}\right)$ and it leaves commuters at motorists' mercies during peak periods. The relatively unplanned nature of the university campus at inception influences the reasons why the above factors were highly influential. For instance, some facilities are farther away from central activity areas for instance, Obafemi Awolowo Hall, Faculty of Engineering, Awda dam and thus often depend on motorcycles while some were closer to central activity areas such as the faculty of arts, Mellanby Hall, Kuti Hall, and Theatre Arts. Lack of effective planning at inception gave motorcyclists opportunity to help connect these areas that are like satellite to other areas in the campus. From the foregoing analysis, it was observed that the ban of CMO had great impact on activities on campus and the underlying factor that support motorcycle operation within the campus is the poor planning of the university. Although, through the efforts of the physical planning unit of the university, there have been reforms, such as the master plan prepared for the university in 2003, but none of their efforts have been able to correct this poor physical planning at inception. 
Table 3.8: weighted opinions assessment of Impacts of ban of CMO on traffic behavior within the campus

\begin{tabular}{|c|c|c|c|c|c|}
\hline Impact of activities on campus & Agree & $\%$ & Disagree & $\%$ & Rank \\
\hline Increases waiting time at bus stop & 306 & 87.4 & 44 & 12.6 & $1^{\text {st }}$ \\
\hline Getting late to classes/seminars & 265 & 75.7 & 85 & 24.3 & $7^{\text {th }}$ \\
\hline Increase in struggle for shuttles, cabs and tricycle at peak period & 278 & 79.4 & 72 & 20.6 & $4^{\text {th }}$ \\
\hline Increase in transportation cost as motorists prefer drops & 208 & 59.4 & 142 & 40.6 & $9^{\text {th }}$ \\
\hline $\begin{array}{l}\text { Difficulty for those living in far residences to connect vehicles } \\
\text { plying their route }\end{array}$ & 294 & 84.0 & 56 & 16.0 & $3^{\text {rd }}$ \\
\hline $\begin{array}{l}\text { Increase tensions during early morning exams and long queue at } \\
\text { bus stops }\end{array}$ & 299 & 85.4 & 51 & 14.6 & $2^{\text {nd }}$ \\
\hline $\begin{array}{l}\text { Leave commuters at motorists mercies during peak periods } \\
\text { (morning/evening) }\end{array}$ & 277 & 79.1 & 73 & 20.9 & $5^{\text {th }}$ \\
\hline Challenges of looking for change for cabs & 269 & 76.9 & 81 & 23.1 & $6^{\text {th }}$ \\
\hline Increase difficulty to get to places of worship at weekend & 261 & 74.6 & 89 & 25.4 & $8^{\text {th }}$ \\
\hline
\end{tabular}

Source: Authors' Analysis, 2020.

\subsection{Impacts of ban of CMO Traffic Behavior of university commuters}

\subsection{Main purpose of trips within the campus}

Table 3.9 reveals that a majority $(85.3 \%)$ of students make trips for educational purposes while other trip purposes accounted for $14.3 \%$ apart from work. For staff, nine-tenths $(90.0 \%)$ of sampled staff main purpose of trip is for work while other purposes takes the other share. Based of priori expectation, this is expected. However, the implication of this results is the direct impacts any negative transport policy will have on student education and journey to work of staff. Thus, there ought to be impact analysis of transport policy before implementation.

Table 3.9: Main Purpose of Trips

\begin{tabular}{|c|c|c|c|c|c|c|c|}
\hline \multirow[t]{2}{*}{ Type of commuter } & \multicolumn{6}{|c|}{ Main Purpose of Trips } & \multirow[t]{2}{*}{ Total } \\
\hline & Educational purpose & $\%$ & Work & $\%$ & Others & $\%$ & \\
\hline Student & 256 & 85.3 & 1 & 0.3 & 43 & 14.3 & 300 \\
\hline Staff & 2 & 4.0 & 45 & 90.0 & 3 & 6.0 & 50 \\
\hline $\mathrm{N}$ & 258 & 73.7 & 46 & 13.1 & 46 & 13.1 & 350 \\
\hline
\end{tabular}

Source: Authors' Analysis, 2020.

\subsection{Frequency of work day trips of commuters in the University of Ibadan}

It is observed from Table 3.10 that more than half (57.3\%) of sampled students made about 7-12 trips during the working week and more two-fifths (42.0\%) made between 1-6 trips. For staff, more than half $(52.0 \%)$ made between 7-12 trips and 48\% made between 1-6 trips. The mean frequency of trips on work day (7-12) trips is higher than mean frequency on weekends (1-4 trips) (see Table 3.11). The conclusion that can be drawn from the foregoing analysis is that commuters use make more trips during the week than during the weekends, thus an increased difficulty if there are not integrated transport system.

Table 3.10: Commuters' frequency of work day trips

\begin{tabular}{llllllll}
\hline Commuter & $\begin{array}{l}\text { Between } \\
\text { trips }\end{array}$ & $1-6$ & $\%$ & Between 7-12 trips & $\%$ & Above 12 trips & $\%$ \\
\hline Student & 126 & 42.0 & 172 & 57.3 & 2 & 0.7 \\
Staff & 24 & 48.0 & 26 & 52.0 & - & - \\
\hline $\mathrm{N}$ & 150 & 42.9 & 198 & 56.6 & 2 & 0.5 \\
\hline
\end{tabular}

Source: Authors' Analysis, 2020.

\subsection{Frequency of weekend trips of university commuters}

The analysis in Table 3.11 shows the frequency of trips per weekend. It was gathered that more than two -thirds $(63.7 \%)$ of sampled students made between 1-4 trips during the weekends, while about one-third $(36.3 \%)$ had between 5-8 trips/weekend. For the staff, a majority (80.0\%) of sampled staff had between 1-4 trips per weekend before ban and about 20\% made between 5-8 trips during the weekend. This result, therefore shows more frequency (\%) of trips for staff than students on weekends and mean trips at weekend's ranges between 1-4 trips. That more staff commute during weekends is plausible as they have more contact with the town than most students who migrated from other parts of the country for academic purposes. 
Table 3:11: Frequency of trips at weekends of university commuters

\begin{tabular}{lllll}
\hline Commuter & $1-4$ trips & $\%$ & $5-8$ trips & $\%$ \\
\hline Student & $\mathbf{1 9 1}$ & $\mathbf{6 3 . 7}$ & $\mathbf{1 0 9}$ & $\mathbf{3 6 . 3}$ \\
\hline Staff & $\mathbf{4 0}$ & $\mathbf{8 0 . 0}$ & $\mathbf{1 0}$ & $\mathbf{2 0 . 0}$ \\
\hline $\mathrm{N}$ & $\mathbf{2 3 1}$ & $\mathbf{6 6 . 0}$ & $\mathbf{1 1 9}$ & $\mathbf{3 4 . 0}$ \\
\hline
\end{tabular}

Source: Authors' Analysis, 2020.

\subsection{Hypothesis Testing}

H0: There is no significant difference in the average cost of trips before ban and after the ban of CMO.

H1: There is significant difference in the average cost of trips before and after the ban of CMO.

Paired Sample T-test analysis was adopted for the analysis. The test includes the paired samples correlation, paired sample descriptive statistics summary and the paired samples test respectively. Paired t-test is used to compare the means of two populations in which samples in one sample compared with the other sample.

Paired samples correlation

The paired samples correlation revealed a positive (0.593) relationship which is significant $(\mathrm{p}=.000)$ at $95 \%$ confidence interval (Table 3.12).

Table 3.12: Paired Samples Correlations

\begin{tabular}{clccc}
\hline & & $\mathrm{N}$ & Correlation & Sig. \\
\hline Pair 1 & $\begin{array}{l}\text { Average Cost per trip before ban \& } \\
\text { Average Cost per trips after ban }\end{array}$ & 233 & .593 & .000 \\
\hline
\end{tabular}

Source: Authors' Analysis, 2020.

Descriptive statistics of Paired samples

The mean cost per trip before ban of CMO is \#172.32 while after the ban it become \#187.60 after the ban (Table 3.13).

Table 3. 13: Paired Samples Statistics

\begin{tabular}{llrrrr}
\hline & & Mean & N & Std. Deviation & Std. Error Mean \\
\hline \multirow{2}{*}{ Pair 1 } & Average Cost per trip before ban & 172.32 & 233 & 127.563 & 8.357 \\
& Average Cost per trips after ban & 187.60 & 233 & 129.519 & 8.485 \\
\hline
\end{tabular}

Source: Authors' Analysis, 2020.

Paired Samples Test

The average cost per trips after the ban (187.60) was greater than the average cost per trip (172.32) before the ban of CMO by 15.279. The difference is statistically significant $(\mathrm{p}=.045)$ (Table 3.14).

Test 3.14: Paired Samples Test

\begin{tabular}{|c|c|c|c|c|c|c|c|c|c|}
\hline & & \multicolumn{5}{|c|}{ Paired Differences } & \multirow[t]{3}{*}{$\mathrm{T}$} & \multirow[t]{3}{*}{ df } & \multirow{3}{*}{$\begin{array}{l}\text { Sig. } \\
(2- \\
\text { tailed })\end{array}$} \\
\hline & & \multirow[t]{2}{*}{ Mean } & \multirow[t]{2}{*}{$\begin{array}{c}\text { Std. } \\
\text { Deviation }\end{array}$} & \multirow[t]{2}{*}{$\begin{array}{l}\text { Std. } \\
\text { Error } \\
\text { Mean }\end{array}$} & \multicolumn{2}{|c|}{$\begin{array}{l}95 \% \text { Confidence } \\
\text { Interval of the } \\
\text { Difference }\end{array}$} & & & \\
\hline & & & & & Lower & Upper & & & \\
\hline $\begin{array}{l}\text { Pair } \\
1\end{array}$ & $\begin{array}{l}\text { Average Cost } \\
\text { per trip before } \\
\text { ban - Average } \\
\text { Cost per trips } \\
\text { after ban }\end{array}$ & 15.279 & 115.933 & 7.595 & 30.243 & -.315 & $2.012^{-}$ & 232 & .045 \\
\hline
\end{tabular}

Source: Author's Analysis, 2020.

\subsection{Modal choice of Commuters before and after ban of CMO}

\subsubsection{Modal choice of Commuters before the ban of CMO}

The analysis in Table 3:15 reveals that about two-thirds $(60 \%)$ of students uses motorcycle before it was proscribed a year ago, about one-fifth (21\%) uses cabs, about $16.7 \%$ uses shuttle/ buses and $2.3 \%$ uses bicycles. For staff, about two-fifths (42\%) of surveyed staff also uses motorcycles, $34.0 \%$ uses cabs as modal choice with relative share for bicycles and buses. From the foregoing, it was gathered that motorcycle was the modal choice for both student and staff before the ban of motorcycles. 
Table 3.15: Commuters' modal choice before ban of CMO

\begin{tabular}{llllllllll}
\hline Commuter & Motorcycle & $\%$ & Buses & $\%$ & Cabs & $\%$ & Bicycle & $\%$ & $\mathrm{~N}$ \\
\hline Student & 180 & 60.0 & 50 & 16.7 & 63 & 21.0 & 7 & 2.3 & 300 \\
Staff & 21 & 42.0 & 5 & 10.0 & 17 & 34.0 & 7 & 14.0 & 50 \\
\hline $\mathrm{N}$ & 201 & 57.4 & 55 & 15.7 & 80 & 22.9 & 14 & 4.0 & 350 \\
\hline
\end{tabular}

Source: Authors' Analysis, 2020.

\subsubsection{Modal choice of Commuters after the ban of CMO}

Detailed in Table 3.16 is the modal choice of commuters after the ban of commercial motorcycle. It was observed that student opted for tricycle after the ban of motorcycle as seven-tenths $(70 \%)$ of sampled students opted for tricycle, about one-fifth (20.7\%) uses cab and about $2.7 \%$ switches to walking. Though, walking is the fundamental mode of transport and almost every trip begins and end with walking and it has been found beneficial but roads within the campus lack adequate pedestrian access in their designs. For staff, more than half (54\%) sampled staff switches to cab from motorcycle and about two-fifths $(42 \%)$ changes their modal choice to tricycle. The conclusions that can be drawn from the foregoing analysis is that commuters in the university campus prefer personalized vehicles (motorcycle, tricycle and cabs) than buses/shuttles. This would increase numbers of vehicles and also pollution of the air within the campus.

Table 3.16: Commuters modal choice after ban of CMO

\begin{tabular}{llllllllll}
\hline Commuter & Tricycle & $\%$ & Buses/shuttles & $\%$ & Cabs & $\%$ & walk & $\%$ & N \\
\hline Student & 210 & 70.0 & 20 & 6.7 & 62 & 20.7 & 8 & 2.7 & 300 \\
\hline Staff & 21 & 42.0 & 1 & 2.0 & 27 & 54.0 & 1 & 2.0 & 50 \\
\hline N & 231 & 66.0 & 21 & 6.0 & 89 & 25.4 & 9 & 2.6 & 350 \\
\hline
\end{tabular}

Source: Authors' Analysis, 2020.

\subsection{Hypothesis Testing}

Hypothesis Two

H0: There is no significant difference between commuters' modal mode of transport before and after ban of CMO. H1: There is significant difference between commuters' modal choice of transport before and after ban of CMO. Chi square analysis was used to test the test. Chi square reveals a chi square value of $74.235 \mathrm{df}$ (9) which is significant at $(\mathrm{p}=.000)$ at $95 \%$ confidence interval. Thus, the null hypothesis is rejected and the alternative hypothesis accepted, this implies that there is a statistically significant difference between commuters' modal choice before ban of ban of CMO and after the ban.

Table 3.17: Chi-Square Tests

\begin{tabular}{lccc}
\hline & Value & Df & Asymp. Sig. (2-sided) \\
\hline Pearson Chi-Square & $74.235^{\text {a }}$ & 9 & .000 \\
Likelihood Ratio & 77.520 & 9 & .000 \\
Linear-by-Linear Association & .965 & 1 & .326 \\
\hline N of Valid Cases & 350 & & \\
\hline
\end{tabular}

Source: Authors' Analysis, 2020.

\subsection{Conclusion and recommendations}

This study set out to investigate the impacts of the ban of commercial motorcycle operations in the university system. The study revealed that there have been significant negative impacts of ban of commercial motorcycle operations on university commuters especially as it relates to traffic behavior, cost of trips, change of modal choice and psychological costs such as costs, delays, increase waiting time, congestion etc. Transport demand is a derived demand, hence its impacts will be seen through its opportunity cost that might not be in monetary units only, for instance, lateness to class/ work as a result of long queue at peak period. Also, the study revealed that there is negative impacts of the ban on students, especially females than on the staff, this is based on differences in socioeconomic status (age differentials, stipend/income differentials, vehicle ownership etc.) between staff and students. Areas farther from the central places are placed at a disadvantage because of long waiting time and few motorists plying those routes because of low demand, a situation mitigated by motorcycle. The tricycle have not been able to perform efficiently in this regards.

It is important that university transportation planning must be inclusive, thus opinions and aspirations of students and staff must be incorporated in university transportation policy. A sound university transportation policy must help achieve the following, develop transport infrastructure, improvement in transportation services and management of commuters demand. Thus, participatory transportation planning is suggested in university system. Hence, the views of all relevant stakeholders, which should include beneficiaries (students, staff, etc.) and experts (transport planners, physical planners, etc.) should be considered and incorporated in university transport planning. 
There is an observed complex relationship between transportation and land use. The evolution of the setting of the university of Ibadan begins without an effective master plan and transport plan, thus necessitating weak land use planning, siting of mutually incompatible facilities within the same zone, for instance the siting of male residential areas within central administrative areas and inaccessibility of some facilities especially female hostels and quarters (residential) thus creating accessibility problem, a situation that influence the use of motorcycle operations to serve the unreached areas. The foregoing led to the creation of the physical planning unit in the year 2000 to patch up the hodgepodge. However, despite changes in land use development overtime, there have been corresponding changes to transportation, a failure of integration of transport policy framework in physical development plan of the campus.

Based on the foregoing, it synergize changes in physical development of the university with an effective campus transportation model that can accommodate both motorized and non-motorized transport. Thus, the outright ban of commercial motorcycle operations in the campus without an effective transportation model linked to changes in physical development of the campus would be counterproductive university physical development and also exacerbates the problem of accessibility faced by most female students and staff staying the quarters.

Also, future land use development within the campus should integrate transportation planning that could reduce distance covered, improves accessibility and provision of road infrastructure that could encourage inter-modality which should include motorcycle, bicycle and walking, expansion and creation of new road infrastructure such that waiting time, access time and walking distance based on acceptable approved planning standards. Motorcycle operations as a mode of transport within university campus has more benefits than its cost, especially for student, hence, this study suggested its restoration and adoption within university system, however, it can be modernized to e-transport.

\section{References}

Adeniji, A. S. (1981). "Public Transport and Urban Development Strategy in Nigeria", Ph.D. Thesis, University of Wales.

Asekhame F.F. and Oisamoje M.D (2013). Ban on commercial Motorcycle Operations in Benin City, Nigeria: An Appraisal of the Benefits and Business Opportunities. Developing Country Studies. www.iiste.org. Vol. 3 No.14.

Barter, P. A., (1998). An International Comparative Perspective on Urban Transport and Urban Form in Pacific Asia: the Challenge of Rapid Motorization in Dense Cities. Doctoral Dissertation, Murdoch University.

Busari A. et al. (2015) Travel Behavior of University Environment: Inter -Relationship Between Trip Distance and Travel Mode Choice in South-Western, Nigeria. International Journal of Applied Engineering Research Vol. 10, Issue 21 pp. $42362-42366$.

Deng, X., Xu, J., Wang, B., (2009). Traffic Countermeasures Research for Guangzhou City in Traffic Mode Transferring Period after "Motorcycle Forbidden Ban Effect." Journal of Transportation Systems Engineering and Information Technology 9(4), 145-150.

Gadonu, A. et al, (1979) "Final Report of Planning Studies on the Metropolis of Lagos", Unpublished Official Report Submitted to the Lago State Government. Nigeria Institute Social Economic Social Economic Research (NISER) Seminar.

Ikot, A.S. et al. (2011). Motorcycle ban and its economic implications in Uyo metropolis of Akwa Ibom State, Nigeria. International Journal of Economic Development Research and Investment. Vol. 2(3): 32-39.

Inaba H. and Kato H. (2017) Impacts of Motorcycle Demand Management in Yangon, Myanmar, Transportation Research Procedia 25c 4856-4872 World Conference on Transport Research -WCTR 2016. Available online at www. Sciencedirect.com

Inuwa $\mathrm{N}$ et al. (2017) An Appraisal of Socio-Economic Impacts of Commercial Motorcycles in Gombe State, Nigeria. International Journal of Asian Social Science. Vol. 7 issue 6, Pp. 480-488

Koizumi, Y., et al. (2013). Urban Transportation Characteristics and Urban Mass Transit Introduction in the Cities of Developing Countries. Journal of the Eastern Asia Society for Transportation Studies. Vol. 10, pp. 81-99.

Kumar A. (2011). Understanding the emerging role of motorcycle in African cities: A political economy perspective. SSATP Discussion Paper, No. 13.

Limanond, T., Butsingkorn, T., Chermkhunthod, C., (2011), "Travel behavior of University students who live on campus: a case study of a rural university in Asia". Transport Policy 18, 163-171.

Michael, C.E., et al. (2013). Abolition of motorbikes and its implication on transportation and criminality in Calabar metropolis. International Journal of Social Sciences Studies, 1(1): 206-214.

Muromachi, Y., (2008), "Commuting mode choice and health". International Association of Traffic and Safety Sciences Review 33 (3), 36-41.

Ndiribe, Okey. (2009). "Surging Rate of Motorcycle Accident in Lagos State", Sunday Vanguard.

Ogunsanya A. A. and Galtima, M. (1993). "Motorcycle in Public Transport Service in Nigeria: Case Study of Yola Town”, in J.S. Ikya (ed.), Urban Passenger Transportation in Nigeria. Ibadan: Heineman 
Olubomehin, O.O. (2012). The Development and Impact of Motorcycles as Means of Commercial Transportation in Nigeria. Research on Humanities and Social Sciences, 2, 231-239.

Oyesiku, O. O. (2002). "From Womb to Tomb" 24th Inaugural Lecture, Olabisi Onabanjo University. Ago Iwoye: OOU Press.

Physical Planning Unit, University of Ibadan, Nigeria

Rodriguez, D., and Joo, J., (2004)." The relationship between non-motorized mode choice and the local physical environment". Transportation Research Part A 9, 151-173.

Shannon, T., et al. (2006), "Active commuting in a university setting: assessing commuting habits potential for modal change", Transport Policy, Vol. 13 No. 3, pp. 242-253.

Tolley, R. (1996), "Green campuses: cutting the environmental cost of commuting", Journal of Transportation Geography, Vol. 4 No. 3, pp. 213-217.

Tuan, V. A., Shimizu, T., (2005). Modeling of Household Motorcycle Ownership Behavior in Hanoi City. Journal of the Eastern Asia Society for Transportation Studies 6, 1751-1765.

University of Ibadan Archives and records www.ui.edu.ng/history

VanDrasek B.J. and Adams J.S (2009). College and University Campuses in Greater Minnesota as Traffic Generators. Center for Transportation Studies, University of Minnesota, Minneapolis.

Ye, L., Wang, Q., (2011). Case Study of Motorcycle Use and Policy Analysis in Huizhou, China. Journal of Transportation Engineering 137, 831-836. 